\title{
Stem Cell Therapy for Post-Traumatic Stress Disorder: A Novel Therapeutic Approach
}

\author{
Dhir Gala *(D), Vikram Gurusamy, Krishna Patel, Sreedevi Damodar ${ }^{D}$, Girish Swaminath and Gautam Ullal \\ Department of Neuroscience, American University of the Caribbean School of Medicine, \\ 1 University Drive at Jordan Dr, Cupecoy, Sint Maarten; vikramgurusamy@students.aucmed.edu (V.G.); \\ krishnakpatel@students.aucmed.edu (K.P.); sreedevidamodar@students.aucmed.edu (S.D.); \\ girishswaminath@students.aucmed.edu (G.S.); gullal@aucmed.edu (G.U.) \\ * Correspondence: dhirgala@gmail.com or dhirgala@students.aucmed.edu
}

check for updates

Citation: Gala, D.; Gurusamy, V.; Patel, K.; Damodar, S.; Swaminath, G.; Ullal, G. Stem Cell Therapy for Post-Traumatic Stress Disorder: A Novel Therapeutic Approach. Diseases 2021, 9, 77. https://doi.org/ $10.3390 /$ diseases 9040077

Academic Editor: Claudia Altomare

Received: 19 August 2021

Accepted: 25 October 2021

Published: 29 October 202

Publisher's Note: MDPI stays neutral with regard to jurisdictional claims in published maps and institutional affiliations.

Copyright: (c) 2021 by the authors. Licensee MDPI, Basel, Switzerland. This article is an open access article distributed under the terms and conditions of the Creative Commons Attribution (CC BY) license (https:// creativecommons.org/licenses/by/ $4.0 /)$.

\begin{abstract}
Stem cell therapy is a rapidly evolving field of regenerative medicine being employed for the management of various central nervous system disorders. The ability to self-renew, differentiate into specialized cells, and integrate into neuronal networks has positioned stem cells as an ideal mechanism for the treatment of epilepsy. Epilepsy is characterized by repetitive seizures caused by imbalance in the GABA and glutamate neurotransmission following neuronal damage. Stem cells provide benefit by reducing the glutamate excitotoxicity and strengthening the GABAergic inter-neuron connections. Similar to the abnormal neuroanatomic location in epilepsy, post-traumatic stress disorder (PTSD) is caused by hyperarousal in the amygdala and decreased activity of the hippocampus and medial prefrontal cortex. Thus, stem cells could be used to modulate neuronal interconnectivity. In this review, we provide a rationale for the use of stem cell therapy in the treatment of PTSD.
\end{abstract}

Keywords: stem cell therapy; pluripotent stem cells; cell therapy; applications; post-traumatic stress disorder; epilepsy

\section{Introduction}

Post-traumatic stress disorder (PTSD) is a psychiatric disorder characterized by difficulty recovering from an exposure to an exceptionally threatening/horrifying event or to a prolonged trauma. Exposures may include serious accidents, natural disasters, combat/war, rape or death threats [1]. PTSD presents as persistence of intrusive recollections, avoidance of trauma-related stimuli, negative alterations in mood, and hyperarousal symptoms for greater than one month [1]. Events can be relived through nightmares and flashbacks leading to feelings of sadness, anger, or fear and further leading to detachment from others. It can present as a significant health burden by increasing the risk of suicide and other medical conditions [2]. The lifetime prevalence of PTSD is between $1.5 \%$ and $8.8 \%$. The prevalence among U.S. adults is $3.5 \%$, with women twice as likely to have PTSD than men. PTSD is highest among U.S. African Americans, Native Americans, and Hispanics/Latinos when compared to non-Hispanic/Latino Caucasians [3-5].

Treatment options for PTSD include psychotherapy and medication, either used alone or in combination. Cognitive processing therapy addresses the negative thoughts surrounding the trauma and confront distorted thought patterns in order to change how they feel or act. Prolonged exposure therapy uses detailed repetitive recollection of the trauma to expose the patient to their symptoms in a controlled and safe environment to improve coping skills [6]. Group therapy allows survivors of traumatic events to feel comfortable and supported in sharing their emotions in a non-judgmental setting. Other psychotherapies include interpersonal, supportive, and psychodynamic therapies focusing on self-regulation and interpersonal relationships [6]. Medications can be used in PTSD for symptomatic relief; however, their efficacy and response rates are low with Selective 
serotonin reuptake inhibitors (SSRIs) such as fluoxetine and paroxetine showing limited efficacy over placebos [7]. Other medications such as serotonin-norepinephrine reuptake inhibitors (SNRIs) have also shown minimal benefit for PTSD symptoms. The first-line medications used for PTSD include sertraline, fluoxetine, paroxetine, and venlafaxine. Prazosin is an alpha- 1 adrenergic antagonist used to reduce nightmares in PTSD, but studies show variability in its efficacy for symptom improvement. The prevalence of treatment-resistant PTSD is approximately 33\%. Current non-pharmacological therapies for PTSD have limited availability and pharmacological management can lead to significant adverse effects [8]. PTSD is a chronic condition for many patients and commonly recurs or resists treatment, suggesting the need to explore further therapeutic options.

The pathophysiology of PTSD involves abnormal neural connectivity between the amygdala, hippocampus, and medial prefrontal cortex (mPFC). PTSD and temporal lobe epilepsy have similar abnormal neuroanatomic neural networks. Both disorders have functional abnormalities in the anterior mesial temporal lobe and neural pathways involving the temporal lobe implicating similar therapeutic options could be used for both disorders [9-13]. In epilepsy, repeated abnormal paroxysmal electrical discharges and seizure activities lead to progressive neuronal cell damage [14]. In temporal lope epilepsy, the hippocampus becomes the common target of neuronal injury. This can induce neurogenesis, apoptosis, and neuronal impairment with limited GABAergic receptor expression resulting in anxiety, depression, and cognitive impairment [15]. More recently, epilepsy has been considered a candidate for stem cell therapy for use in prophylaxis and enhancement of cognitive function. By using stem cell therapy and modifying the expression of specific neurotrophic factors, impairment can be reduced in the affected areas and provide better outcomes [16]. Studies in children have shown use for stem cell therapy in treatmentresistant cases [17]. Targeting stem cell therapy to the amygdala and hippocampal regions of the brains can further help to manage the complications of epilepsy [18]. Stem cell therapy has been used to treat the neuropsychiatric components of epilepsy. By nature of their similarities in neuroanatomic neural networks, stem cells could be utilized for the treatment of PTSD. Loss or over-activation of neuronal nuclei or their projections in the amygdalohippocampal circuit are implicated in the pathogenic mechanism of both epilepsy and PTSD. Therefore, we suggest that stem cell therapy targeting specific regions of the brain to enhance the growth of new neurons could be used in the treatment of PTSD, to reduce symptoms and potentially address the underlying cause of PTSD.

\section{Stem Cell Therapy: Terminology and Cell Lines}

\subsection{Overview}

Stem cell therapies are being extensively used in regenerative medicine, especially in neurological pathologies, due to the low regenerative potential of the central nervous system (CNS). Numerous pre-clinical animal models have shown stem cell therapy to be safe and effective leading to an increasing number of clinical trials [19]. This surge in clinical trials has led to the formation of regulations and guidelines for the use of stem cells in treating various neurological disorders $[20,21]$. Stem cell therapies provide benefit through various mechanisms in the CNS such as replacement of cells, modulating the inflammatory response, and providing neuroprotection [22-24]. These mechanisms vary depending on the source of stem cells. The commonly used stem cells are human pluripotent stem cells (hPSCs), fetal-derived neural progenitor stem cells (fNPCs) and mesenchymal stem cells (MSCs).

\subsection{Human Pluripotent Stem Cells (hPSCs)}

Stem cells such as hPSCs can self-renew and differentiate into specialized tissue types making them useful in regenerative medicine. The two most widely used subtypes of hPSCs include human embryonic stem cells (hESCs) and human induced pluripotent stem cells (hiPSCs). hESCs are obtained from the blastocyst of the growing embryo whereas 
hiPSCs are generated from somatic cells by inducing the expression of four transcription factors: Oct3/4, Sox2, Klf4, and c-Myc [25,26].

The primary use of hPSCs in the clinical setting is through expansion and cell replacement. This cannot occur by direct implantation due to the high risk of cancer by mutations accumulated during the proliferation of undifferentiated tissues as well as the effects of the local microenvironment [27]. Ideally, the cells need to be cultured and differentiated into tissue prior to transplantation. These cells can then be used in various CNS conditions involving the loss of neurons such as Parkinson's disease, spinal cord injury, and Huntington's disease [28-30]. However, these therapies have a risk for immunogenicity even with the use of autologous stem cells [31].

\subsection{Fetal-Derived Neural Progenitor Stem Cells}

fNPCs are cells that are obtained from the fetal brain and spinal cord [32]. These stem cells possess the ability to differentiate into various CNS cell types such as neurons, glial cells and neuroectodermal cells, making them useful for CNS pathologies [33-35]. However, a major limiting factor is the availability of fNPCs; some transplantations may require ten aborted fetuses for one patient [32,36].

The major mechanism of therapy for fNPCs is cell replacement. In primate models of spinal cord injury, intraparenchymal injection of fNPCs proved efficacious and safe with histologic evidence of nerve growth in the injured region [37]. Similar studies have been replicated in rat models of Parkinson's disease, Huntington disease, traumatic brain injury, and stroke with promising results [38-41]. These pre-clinical studies on fNPCs have led to clinical trials for a variety of CNS pathologies including amyotrophic lateral sclerosis, traumatic cervical spinal cord injury, and stroke [42-44].

\subsection{Mesenchymal Stem Cells}

Mesenchymal stem cells (MSCs) are multipotent self-renewing stem cells that are commonly obtained from the bone marrow but can also be found in the umbilical cord, peripheral blood, and adipose tissue [45]. MSCs have been tested mostly in animal models with pathologies of the heart, liver, eye, and blood [46]. However, there are clinical trials using MSCs for conditions such as amyotrophic lateral sclerosis, stroke, spinal cord injury, multiple sclerosis, traumatic brain injury, and epilepsy [47-52]. MSCs delivered intravascularly have a high degree of safety with a meta-analysis showing no increase in acute infusional toxicity, organ system complications, infection, death, or malignancy [53].

\section{Epilepsy}

\subsection{Overview}

Epilepsy is a CNS condition that involves recurrent seizures $(\geq 2)$ more than $24 \mathrm{~h}$ apart, an unprovoked seizure with a probability of subsequent seizures, or a diagnosis of a type of epilepsy syndrome. It affects over 70 million people around the world with the highest risk groups including infants and older aged adults [14]. Causes of epilepsy are broad and up to $60 \%$ of patients have an idiopathic cause of epilepsy [54]. Common etiologies include temporal lobe lesions, cerebrovascular disease post-stroke, primary or metastatic brain tumors, vascular malformations, prior CNS infection such as neurocysticercosis, head injury, and Alzheimer's disease [55].

\subsection{Mechanism}

The pathophysiology of epilepsy can be viewed as a shift in the balance of GABA and glutamate neurotransmission with an increase in glutamate excitatory neurotransmitters due to loss of GABAergic neurons after epileptic insults such as strokes, traumatic brain injury, and status epilepticus. The neuronal circuits are often reorganized to favor abnormal connections -such as in the granule cells of the dentate gyrus collectively called mossy fiber sprouting. The deficit in GABA signaling and enhancement of glutamate signaling is one of the goals in pharmacotherapy [56]. However, research has shown that the mechanism 
of epilepsy is more complex and may involve several neuropeptides. Neuropeptides are important in the mechanism of epilepsy with their release dependent on neuronal activity, typically released during high neuronal firing frequencies, as opposed to neurotransmitters [57]. In the in-vitro single neuron epilepsy model, the firing rate of neurons is abnormally high compared to normal neurons. As a result, targeting neuropeptide receptors has become an alternative option for future pharmacotherapy [58].

Partial onset seizures are the most common form of adult seizures with temporal lobe epilepsy as the most common subset. Temporal lobe epilepsy is thought to be partially caused by the dysregulation of the amygdala and hippocampus activity. Owing to its structural pattern, the hippocampus is one of the most vulnerable foci in the brain for epileptogenesis [59]. In addition, hippocampus and amygdala play a pivotal role in long-term potentiation and memory consolidation [59]. Therefore, deficits in declarative and spatial memory have been specifically implicated with enhancement of emotional memories when these areas are targeted [59]. Deficits in fear conditioning are also seen in temporal lobe epilepsy in those undergoing unilateral lobectomy of the temporal lobe that includes parts of the amygdala and hippocampus [60]. Neuronal loss in either the hippocampus or amygdala leads to damage in both areas due to the interconnectivity; therefore, when the seizures occur in one region, mirror foci develop contralaterally [61].

Animal studies have reported the posteromedial and posterolateral cortical nuclei disappear in temporal lobe epilepsy with severe neuronal loss in addition to damage to a large projection in the lateral amygdala-hippocampal area that provides emotional sensory input for hippocampal processing [62]. The emotional significance of memories could be affected in temporal lobe epilepsy if hippocampal-dependent. The lateral nucleus used for auditory inputs and fear conditioning was additionally affected, suggesting temporal lope epilepsy can lead to behavioral impairments in fear conditioning. The medial nucleus remains intact and has been proposed to be involved in seizure initiation [63].

Seizures in temporal lobe epilepsy are facilitated via decreased inhibition, increased excitability, and decreased seizure threshold [64]. The decreased seizure threshold is caused by a loss of GABAergic neurons, specifically GABAergic somatostatin containing non-pyramidal neurons. The destruction of the GABAergic somatostatin containing neurons increases the spread of seizures and decreases the synchronized activity of the amygdala-hippocampal neuronal circuitry for emotional declarative memory and fear conditioning [65].

Kindling is a widely used model for describing the development of temporal lobe epilepsy [66]. The model describes how a single seizure can increase the likelihood of subsequent seizures as the seizure threshold lowers. Kindling leads to a lasting change in brain function, predisposing to neuropsychiatric symptoms [67]. A new study in 2021 on mice used optokindling to activate pyramidal cells in the piriform cortex which disrupted GABA production in feedback inhibitory cells, thereby increasing seizure severity and frequency [68]. Alterations in neuronal circuitry after recurrent seizures could be a potential target for therapy to reduce the adverse effects of epilepsy and the progression of kindling, thereby, decreasing neuropsychiatric symptoms [68].

\subsection{Stem Cell Therapy for Epilepsy}

While pharmacotherapy can be used to treat epilepsy, it can induce detrimental side effects and is largely limited to symptomatic treatment rather than prevention. Surgery, while effective in reducing seizure initiation, is invasive with numerous adverse effects and may not be a viable treatment option for all patients. Stem cell therapy has been considered as an alternative to medications and surgery and has proven to be effective in addressing other neurological disorders, such as spinal cord injury and stroke [69]. In a study conducted in Belarus, 22 patients with refractory epilepsy were split into 10 patients in a stem cell therapy group and 12 patients in a control group [52]. A total of $70 \%$ of the stem cell therapy group showed transformations of generalized tonic-clonic seizures to simple or complex partial seizures, 50\% showed improvement in cognitive status, and 60\% 
demonstrated improvement in anxiety. There was a significantly higher number of responders in the cell therapy group compared to the control. Further, the cell therapy group had a significant reduction in monthly seizure frequency, seizure severity and anxiety compared to control group [52]. In another pilot study, one patient, who initially had epileptic seizures 20-40 times per week, had the episodes decrease in frequency, to 14 episodes per week, after two rounds of bone-marrow derived CD271 + MSCs transplantation [17].

hESCs have the capacity to differentiate into different cell types of the three germ layers and can replace damaged neural cells with healthy stem cells. A study using mice models of status epilepticus showed that neural progenitor cells have the capacity to differentiate into mature neurons after transplantation into the hippocampi [18]. Further research trials suggest hESCs could be used as a means of treatment and prevention of epilepsy with MSCs triggering the release of neurotrophic factors and immunomodulation to reduce the occurrence of seizures [70]. In addition, MSCs have neuroprotective effects by suppressing glutamate toxicity and oxidative injury [70]. An in vitro study demonstrated that MSCs can suppress the expression of the glutamate receptors, including GluR1 AMPA receptors AMPAR subunit as well as the expression of NR1 and NR2A (both NMDAR subunits), yielding reduced glutamate excitotoxicity and reactive oxygen species (ROS) accumulation [71]. hESCs can significantly decrease the frequency and severity of spontaneous seizures and help improve learning and cognitive defects associated with status epilepticus [72].

Stem cell therapy can yield attenuated neuronal death, increased synthesis of neural cells, decreased microglia and astrocyte reactivity, and modulation of neuroinflammation [73]. As astrocyte dysfunction is a common feature in the mechanism of epilepsy, certain stem cells can differentiate into functioning astrocytes [73]. According to another study, MSC derived exosomes attenuated astrocyte dysfunction and neuroinflammation in mice models of status epilepticus, in addition to demonstrating improvement in cognition, learning, and memory [73]. Another approach to stem cell therapy for epilepsy management includes stimulating GABAergic interneurons, as recurrent epilepsy can diminish the prevalence of GABAergic interneurons responsible for inhibitory control in affected brain regions [74]. Cells derived from medial ganglionic eminence (MGE) that are GABAergic progenitors migrate after grafting into the different layers of the hippocampus, leading to a reduction of spontaneous recurrent seizures and reduced abnormal neurogenesis as demonstrated by a mouse model of temporal lobe epilepsy [75]. The formation of synapses by axons of graft-derived GABAergic interneurons with the dendrites of the host CA1 pyramidal neurons plays a significant role in the reduction of spontaneous recurrent seizures, as does reduced EEG amplitude in between seizure episodes [75].

Epileptic seizures can induce anomalous neurogenesis, apoptosis, and neuronal impairment, along with limited GABAergic receptor expression [64]. In epilepsy, the induction of neurogenesis is correlated with significant cognitive impairment, anxiety, and depression [15]. Modifying the expression of neurotrophic factors like brain-derived neurotrophic factor (BDNF) and glial cell line-derived neurotrophic factor (GDNF) could be a potential approach for stem cell therapy [68]. Endothelial progenitor cells are known to increase the expression of BDNF and autophagy-related proteins while improving neuronal circuitry, thereby reducing impairment to learning, memory, and anxiety [16]. Furthermore, in a research study, after one and/or multiple rounds of CD271+ bone marrow MSCs implantation, patients with prior extrapyramidal abnormalities experienced more severe emotional reactions and facial expressions, stronger motor development, better speech, and increased eye and head reactivity to visual and auditory stimuli [17]. Through various target neuronal circuitry such as neurotrophic factors, glutamate receptors, GABAergic interneurons, and astrocytes, stem cell therapy is considered effective in the management of epilepsy. Consequently, it can be utilized to treat neuropsychiatric conditions with similar pathophysiological mechanisms, including but not limited to PTSD. 


\section{PTSD}

\subsection{Overview}

PTSD is the persistence of intrusive recollections, avoidance of trauma-related stimuli, negative alterations in mood, and hyperarousal symptoms after exposure to an exceptionally threatening or horrifying event or to prolonged trauma [1]. While many people show capacity to recover after exposure to trauma, it remains a challenge to predict who will develop PTSD [76]. Patients are at increased risk of experiencing poor physical health including somatoform, cardiorespiratory, musculoskeletal, endocrine, gastrointestinal, genitourinary, integumentary, and immunological disorders burden [2]. It is associated with substantial psychiatric comorbidity, increased risk of suicide, and considerable economic burden [2].

\subsection{Prevalence of PTSD and Treatment-Resistant PTSD}

Under DSM-5 criterion A, the prevalence of exposure to potentially traumatic and other life events over the course of a lifetime is estimated at $89 \%$ [77,78]. Up to $3 \%$ of adults have PTSD at a given moment [79]. Lifetime prevalence rate is between $1.5 \%$ and $8.8 \%$ and in regions of conflict this rate doubles [3-5]. More than half of rape survivors are affected by the condition [80]. Approximately 33\% of people with PTSD have treatment-resistant PTSD. Patients undergoing cognitive behavioral therapy may have non-response rates as high as $50 \%$, and for SSRIs about $20-40 \%$ [81]. In a study of PTSD patients receiving treatment in a primary care setting, the course of the disorder was chronic, with a recovery rate of $38 \%$ and a recurrence rate of $30 \%$ [82].

\subsection{Neuroanatomy and Pathophysiological Mechanism of PTSD}

In healthy individuals, stress activates the amygdala, hippocampus, and rostral anterior cingulate cortex for appropriate consolidation of fear memory and extinction of fear. This includes encoding the explicit memory of the stressor, identifying safe contexts relative to the stressor, and habituating appropriately to the stressor (Figure 1). In PTSD, stress hyper-activates the amygdala and there is reduced functional top-down governance of the hippocampus and rostral anterior cingulate cortex over the amygdala, leading to over-consolidation of fear memory and impaired fear extinction.

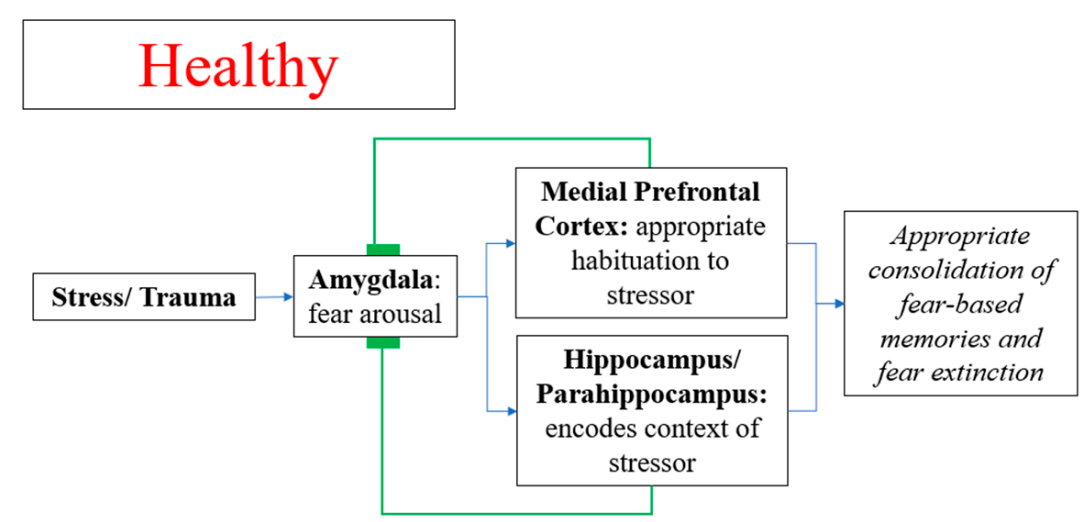

Figure 1. Consolidation of fear memory and extinction of fear in healthy individuals.

Abnormal interactions between the amygdala and the hippocampus and mPFC are thought to underlie PTSD, resulting in over-consolidation of fear-based memories and/or weakened fear extinction, which is the decrease in the conditioned fear response [83,84]. The pathogenic mechanism is thought to be a process of fear conditioning marked by amygdala hyperarousal [84] and reduced mPFC activity, resulting in impaired extinction (Figure 2). Reduced hippocampal/parahippocampal activity is also implicated, resulting in over-generalization of fear to non-threatening stimuli and inability to differentiate safe and threatening contexts $[84,85]$. 


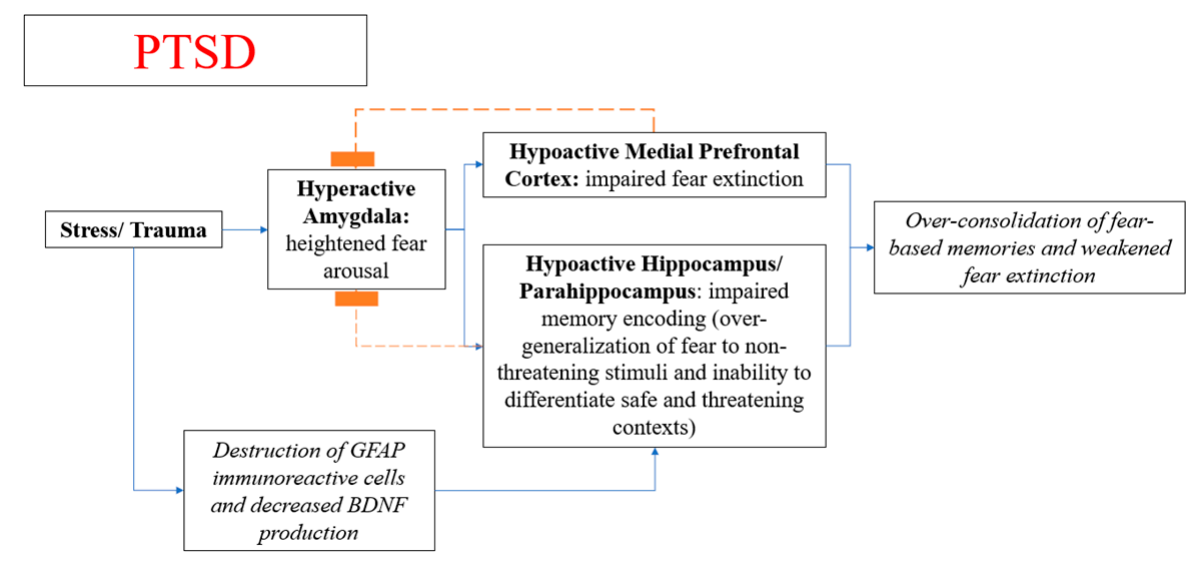

Figure 2. Abnormalities in consolidation of fear memory and extinction of fear memory in individuals with PTSD.

Conditioning of fear and its extinction in humans is associated with activation of both the amygdala and the hippocampal/parahippocampal cortices [83,84]. This is corroborated by functional imaging studies of PTSD patients showing reductions in hippocampal/parahippocampal activity and hippocampal volumes [86-89]. Furthermore, hippocampal/amygdala activity was seen correlated with extinction of conditioned fear by context, indicating that amygdalohippocampal interconnectivity is involved [88]. Consequently, patients with PTSD show reduced ability to process contextual surroundings during extinction of fear [90] and decreased renewal of fear when tested for extinction in a different context from the extinction context [91]. Investigations in human subjects concur with findings from rodent studies indicating that the hippocampal/parahippocampal region plays a major role in distinguishing safe versus threatening contexts and can regulate the activity of amygdala "fear neurons". As patients undergoing exposure therapies for PTSD commonly experience context-dependent relapse of extinguished fear [92], impeding fear renewal via replacement of hippocampal neurons may be a useful therapeutic intervention in this condition.

\subsection{Shortcomings of Current Treatments}

First-line treatment with trauma-focused psychotherapy is preferred to an SSRI in PTSD. An SSRI is a reasonable alternative for patients who prefer it and when cognitivebehavioral therapy cannot be obtained. Multiple clinical trials have shown that the psychotherapies most effective for this condition include exposure therapy, a combined exposure and cognitive therapy known as trauma-focused cognitive-behavioral therapy, as well as eye movement desensitization and reprocessing $[6,93]$. However, these therapies have limited availability and inconsistent treatment outcomes. While some patients have a robust response to treatment, others have poor or partial relief of symptoms requiring restructure of regimen based on predominant symptom clusters, treatment availability and/or patient preference. Studies have shown between $18 \%$ and $50 \%$ of patients with PTSD have a stable recovery within three to seven years, the rest have either a more persistent or chronic course [94]. Furthermore, while it is thought that early treatment of PTSD may prevent its chronicity, this has not been shown empirically, especially for pharmacotherapy [95].

Unfortunately, SSRI may have adverse effects including but not limited to sexual dysfunction, drowsiness, weight gain, insomnia, anxiety, dizziness, headache, and dry mouth [96]. Serotonin norepinephrine reuptake inhibitors (SNRIs) may additionally cause increases in blood pressure, nausea, and diaphoresis among others. Patients may fail to respond to up to two SSRI/SNRI trials until fourth-line treatment with a second-generation antipsychotic (SGA), such as risperidone or quetiapine is indicated. These SGAs have adverse effects including extrapyramidal symptoms, sedation, weight gain, glucose abnormalities, hyperlipidemia, orthostatic hypotension, QTc prolongation, and anticholinergic symptoms as well as others $[8,97]$. 


\subsection{Similarities of PTSD to Epilepsy}

In epilepsy, the loss of inhibitory projection neurons leads to alteration in the synchronized oscillatory activity of amygdalohippocampal circuits and further spread of seizure activity via excitation of the basolateral nucleus of the amygdala, ultimately causing dysfunctionality of both fear conditioning and emotional enhancement of declarative memory. Trauma in PTSD causes amygdala hyperarousal and associated decreases in hippocampal and mPFC activity which ultimately produce the nearly opposing effect of over-consolidation of fear-based memories and impaired fear extinction. As it is either the loss or over-functionality of nuclei or their projections that are implicated in both syndromes, it is plausible that use of stem cell therapies modulating the connectivity of this circuit could be of therapeutic benefit in both conditions [98].

Additionally, seizures are precipitated by stressful events or durations in about half of individuals with epilepsy. It is thought that stress hormones play a role in neuronal excitability. Case studies of PTSD patients have shown a pattern of video electroencephalogram recorded seizure activity related in time to stressful occurrences. Thus, stress exposure has been linked to the development of epilepsy and the susceptibility to stress as a seizure trigger. These findings together suggest that stress-induced epilepsy might be more likely to result in stress-precipitated seizures [99]. Furthermore, PTSD is a known risk factor for psychogenic nonepileptic seizure (PNES), and up to one-third of epilepsy patients treated at tertiary care epilepsy centers have PNES as well. Lastly, temporal lobe epilepsy (TLE) is commonly misdiagnosed as PTSD and vice-versa [99].

\subsection{Behavioral Sensitization and Electrophysiological Kindling}

The process of behavioral sensitization is thought to occur when emotional trauma is connected with episodes of depression, leaving traces of electrophysiological "kindling" which persist after remission. The scar theory of depression presumes that even under moderate or no psychosocial stress, this "scar" of negative concept neuronal connectivity might increase susceptibility to the onset of new depressive episodes [100]. This is supported by associative network theory which predicts that as connections between negative concepts strengthen the "scarring" increases, ultimately lowering threshold for activation and thus increasing susceptibility [100]. These findings together suggest that traumatic experiences and associated strengthening of connections relating to negative concepts could lead to neuronal hyperresponsiveness precipitating seizure-like activity. This relative excitation could potentially be a target of stem cell therapy, as neuronal regeneration could weaken those connections made by trauma just as it does for epileptogenic foci in epilepsy.

\subsection{Stem Cell Therapy in Memory Symptoms, Neuropsychiatric Disorders, and PTSD}

Stem cell therapy for PTSD has been studied in the brains of rats in which human iPSCs were differentiated into neural progenitor cells (NPCs). Induced pluripotent stem cell-derived neural progenitor cell transplantation was shown to promote regeneration and functional recovery after PTSD in rats [101]. It is thought that PTSD affects the brain at a cellular level by reducing the number of GFAP immunoreactive cells as well as decreasing production of BDNF, resulting in hippocampal neuron injury. Hippocampal astrocytes in rats with PTSD manifest morphological alterations including a change in cell polarity towards a more fusiform shape [102]. The animal model showed efficient differentiation of iPSCs into NPCs and glial cells in vivo to replace damaged hippocampal neurons (Table 1). The transplanted cells enhanced the expression of mature neurons, as measured by NeuN levels. These cells also over-expressed BDNF and GDNF, neurotrophic and neuroprotective factors that suggest the potential for further neurogenesis capability (Figure 3). 
Table 1. Summary of results from Liu et al. [101]. Legend: PTSD—post traumatic stress disorder group (as induced by previously established protocol), PBS—-phosphate buffer solution (does not contain any stem cells), iPSC—induced pluripotent stem cells, Day \#-indicates number of days post-transplantation.

\begin{tabular}{|c|c|c|c|c|c|c|}
\hline $\begin{array}{l}\text { Variables } \\
\text { Tested }\end{array}$ & Control & PTSD & PTSD + PBS & $\begin{array}{c}\text { PTSD + iPSC } \\
\text { Day } 7\end{array}$ & $\begin{array}{l}\text { PTSD + iPSC } \\
\text { Day } 14\end{array}$ & $\begin{array}{c}\text { PTSD + iPSC } \\
\text { Day } 21\end{array}$ \\
\hline $\begin{array}{c}\text { Total distance } \\
\text { in Open Field } \\
\text { Test }\end{array}$ & No change & $\begin{array}{l}\text { Significantly } \\
\text { decreased } \\
\text { relative to } \\
\text { control }\end{array}$ & $\begin{array}{l}\text { Significantly } \\
\text { decreased } \\
\text { relative to } \\
\text { control }\end{array}$ & $\begin{array}{l}\text { Increased relative } \\
\text { to PTSD }\end{array}$ & $\begin{array}{l}\text { Increased } \\
\text { relative to } \\
\text { PTSD }\end{array}$ & $\begin{array}{c}\text { Increased relative } \\
\text { to PTSD }\end{array}$ \\
\hline $\begin{array}{c}\text { Interest area } \\
\text { stay time in } \\
\text { Open Field } \\
\text { Test }\end{array}$ & No change & $\begin{array}{l}\text { Significantly } \\
\text { decreased } \\
\text { relative to } \\
\text { control }\end{array}$ & $\begin{array}{l}\text { Significantly } \\
\text { decreased } \\
\text { relative to } \\
\text { control }\end{array}$ & $\begin{array}{c}\text { No significant } \\
\text { change from PTSD }\end{array}$ & $\begin{array}{l}\text { Significantly } \\
\text { increased } \\
\text { relative to } \\
\text { PTSD }\end{array}$ & $\begin{array}{c}\text { Significantly } \\
\text { increased relative } \\
\text { to PTSD }\end{array}$ \\
\hline $\begin{array}{c}\text { Behavior } \\
\text { modification } \\
\text { in Open Field } \\
\text { Test }\end{array}$ & No change & $\begin{array}{l}\text { Significantly } \\
\text { decreased } \\
\text { relative to } \\
\text { control }\end{array}$ & $\begin{array}{l}\text { Significantly } \\
\text { decreased } \\
\text { relative to } \\
\text { control }\end{array}$ & $\begin{array}{c}\text { No significant } \\
\text { change from PTSD }\end{array}$ & $\begin{array}{l}\text { Significantly } \\
\text { increased } \\
\text { relative to } \\
\text { PTSD }\end{array}$ & $\begin{array}{l}\text { Significantly } \\
\text { increased relative } \\
\text { to PTSD }\end{array}$ \\
\hline $\begin{array}{l}\text { Freezing time } \\
\text { in Fear } \\
\text { Conditioning } \\
\text { Test }\end{array}$ & No change & $\begin{array}{l}\text { Significantly } \\
\text { increased } \\
\text { relative to } \\
\text { control }\end{array}$ & $\begin{array}{l}\text { Significantly } \\
\text { increased } \\
\text { relative to } \\
\text { control }\end{array}$ & $\begin{array}{c}\text { Significantly } \\
\text { decreased relative } \\
\text { to PTSD }\end{array}$ & $\begin{array}{l}\text { Significantly } \\
\text { decreased } \\
\text { relative to } \\
\text { PTSD }\end{array}$ & $\begin{array}{c}\text { Significantly } \\
\text { decreased relative } \\
\text { to PTSD }\end{array}$ \\
\hline Astrogliosis & No change & & & $\begin{array}{c}\text { Increased } \\
\text { GFAP (+) astrocytes } \\
\text { compared to } \\
\text { control }\end{array}$ & & $\begin{array}{c}\text { Significantly } \\
\text { increased } \\
\text { GFAP }(+) \text { astrocytes } \\
\text { compared to } \\
\text { control and PBS }\end{array}$ \\
\hline $\begin{array}{c}\text { NeuN } \\
\text { neuronal } \\
\text { maturation } \\
\text { marker } \\
\text { expression }\end{array}$ & No change & $\begin{array}{l}\text { Significantly } \\
\text { decreased } \\
\text { expression } \\
\text { relative to } \\
\text { control }\end{array}$ & $\begin{array}{l}\text { Significantly } \\
\text { decreased } \\
\text { expression } \\
\text { relative to } \\
\text { control }\end{array}$ & $\begin{array}{l}\text { Increased relative } \\
\text { to PTSD+PBS }\end{array}$ & $\begin{array}{l}\text { Increased } \\
\text { relative to } \\
\text { PTSD+PBS }\end{array}$ & $\begin{array}{l}\text { Increased relative } \\
\text { to PTSD+PBS }\end{array}$ \\
\hline $\begin{array}{c}\text { BDNF } \\
\text { expression }\end{array}$ & No change & $\begin{array}{l}\text { Significantly } \\
\text { decreased } \\
\text { expression } \\
\text { relative to } \\
\text { control }\end{array}$ & $\begin{array}{l}\text { Significantly } \\
\text { decreased } \\
\text { expression } \\
\text { relative to } \\
\text { control }\end{array}$ & $\begin{array}{c}\text { Slightly increased } \\
\text { expression relative } \\
\text { to PTSD }\end{array}$ & $\begin{array}{l}\text { Significantly } \\
\text { increased } \\
\text { expression } \\
\text { relative to } \\
\text { PTSD }\end{array}$ & $\begin{array}{c}\text { Significantly } \\
\text { increased } \\
\text { expression relative } \\
\text { to PTSD }\end{array}$ \\
\hline
\end{tabular}

\section{PTSD + iPSCs}

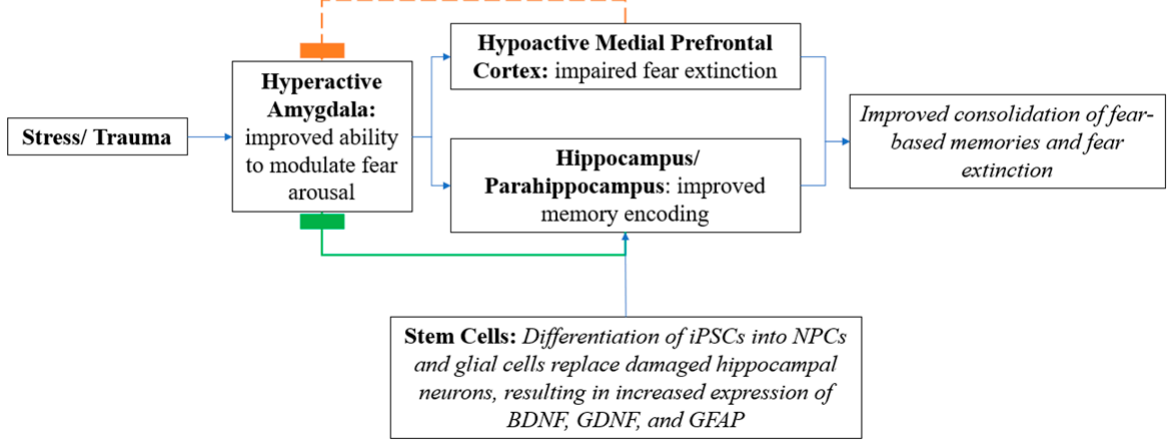

Figure 3. Mechanism of potential beneficial effects from stem cell therapy in individuals with PTSD.

BDNF has been shown to be significantly decreased in animals following PTSD [103]. Memory deficits as a result of PTSD cause reduction in BDNF expression in the hippocampus and deficient performance in hippocampus-dependent tasks. This suggests that an increase in BDNF expression mediates the beneficial effects of iPSC-NPC transplantation. The cells also expressed GFAP, a cytoskeletal protein thought to be necessary for recovery 
processes following injury to the brain. This occurs through the remodeling of astrocytes in response to different physiological and pathological situations [104].

Induced pluripotent stem cell-derived astrocytes were shown to generate increased downstream cytokine production (including IL-1 and TNF) when exposed to IL-1B [105]. They have potential to be utilized in management of PTSD, as immune system dysfunction is a common comorbidity, in particular elevated levels of norepinephrine and impaired glucocorticoid receptor signaling [106]. Modulation of promoters in the glucocorticoid receptor gene can influence gene expression and receptor affinity, thereby serving as a potential mechanism for stem cell modification in the treatment of PTSD. Furthermore, the hypothalamic-pituitary axis tends to be upregulated with sustained increases in corticotrophin-releasing factor in PTSD, and could serve as a target for stem cell therapy [106].

Stem cell therapy has additionally been implicated for treatment in models of neuropsychiatric disorders; however, studies applying stem cells to these disorders are scarce. A study using stem cell therapy in mice found improvement in memory function in mice with brain damage from replicated human diseases such as strokes and dementia. The study used glial cells to stimulate repair mechanisms within the brain to support neurons and limit progression of brain damage. It showed enhancement in new neural connections and myelin production to protect the connections. The study was able to reprogram iPSCs back to an embryonic stem cell-like state. When the cells were removed from the mice after a few months, the repair in the brain was not reversible, suggesting that there is not a reliance on the transplanted stem cells long-term for the treatment to be effective [107].

In Alzheimer's disease, neural precursor cells have been implicated in mice for behavior restoration. These stem cells have been linked to improvements in memory, learning, and behavioral dysfunction [108]. Umbilical cord blood CD34+ cells stimulate angiogenesis leading to positive outcomes in cerebral ischemia mice models, improving memory deficits [109]. BDNF has also been shown to increase the effects of neural precursor cells in rat brains, leading to cognitive improvement related to increased hippocampal synaptic density [110]. In rats, mesenchymal stem cells were injected in the stroke-damaged areas, leading to improved neurobehavioral function and reduction in the volume of the stroke lesion [111]. Inflammatory mononuclear phagocyte microglia have also been studied in their production of neurodegenerative proinflammatory cytokines in Alzheimer's disease [110]. Some studies, on the other hand, have found neuroprotective functions of the microglia such as eliminating plaques and releasing neurotrophic agents [112]. In mice, applying mesenchymal stem cell improved cognitive function and microglia activation, decreasing the inflammatory response [108].

Clinical cases of autistic children receiving CD34+ cells have shown positive responses in areas of the brain undergoing hypoperfusion and ischemia related to the neurophysiology of autism [113]. Additionally, the abnormal migration and reduction in GABAergic interneurons during prenatal development leads to neuronal dyssynchrony in autism, epilepsy, and schizophrenia. In studies using mouse xenografts, human stem cell-derived interneuron precursors were able to differentiate in vivo [114]. When transplanted in rat and mouse models for epilepsy, hPSC-derived interneuron precursors fired action potentials and developed synaptic connections that reduced abnormal seizure activity. However, minimal migration was observed after four to seven months post-transplantation in the host mouse brain. The main benefits of interneuron grafts in these models were seen after numerous months post-transplantation [114]. Human PVECs were also implanted into the host mouse brains, mimicking mouse angiogenesis and allowed for migration of human GABAergic interneurons after transplantation. This allowed for improvement in cell migration and reduced GABA levels that were being released by the brain [115]. This further led to an improvement in the behavioral outcome in preclinical psychiatric disorder models within a month of transplantation, compared to the several months observed with solely interneuron precursors [116]. With cotransplantation, the prenatal forebrain developed 
angiogenesis and showed potential for regeneration and repair in adult brains to help improve psychiatric behaviors, particularly behavioral function [117].

\section{Conclusions: Stem Cell Therapy for PTSD}

Stem cells are currently being employed in the treatment of focal epilepsies that share similar neuroanatomical targets with PTSD. Targeting the amygdala in epilepsy using stem cells provides benefit by reducing the complications, centers of epileptic activity and neuropsychiatric comorbidities of epilepsy. It follows that such therapy could be used in conditions which have a similar neuronal basis, such as PTSD. Animal models in rats have provided proof-of-concept for how stem cells can influence functional outcomes in PTSD, as transplanted induced-pluripotent stem cells have shown the capability to differentiate into and replace damaged neuronal and glial tissue, secrete protective neurotrophic factors, and promote neuronal regeneration. Additionally, stem cells could help re-establish regulation of the abnormal pro-inflammatory cascade implicated in PTSD and potentially mitigate development of the condition in addition to reducing symptom intensity. Stem cell therapy could potentially be used for treatment resistant PTSD with milder side effects compared to current treatment regimens. Now that animal research has begun to demonstrate the utility of stem cells in treating PTSD, it has opened doors for future clinical trials.

Author Contributions: All authors contributed to conceptualization, methodology, resources, writing - original draft preparation and writing - review and editing. All authors have read and agreed to the published version of the manuscript.

Funding: The American University of the Caribbean School of Medicine SARC provided financial support for publication fees.

Institutional Review Board Statement: Not applicable.

Informed Consent Statement: Not applicable.

Conflicts of Interest: The authors declare no conflict of interest.

\section{References}

1. Bonanno, G.A. Loss, trauma, and human resilience: Have we underestimated the human capacity to thrive after extremely aversive events? Am. Psychol. 2004, 59, 20-28. [CrossRef] [PubMed]

2. Dadic-Hero, E.; Toric, I.; Ruzic, K.; Medved, P.; Graovac, M. Comorbidity-A troublesome factor in PTSD treatment. Psychiatr. Danub. 2009, 21, 420-424.

3. Alonso, J.; Angermeyer, M.C.; Lepine, J.P. European Study of the Epidemiology of Mental Disorders P. The European Study of the Epidemiology of Mental Disorders (ESEMeD) project: An epidemiological basis for informing mental health policies in Europe. Acta Psychiatr. Scand. 2004, 109 (Suppl. 420), 5-7. [CrossRef] [PubMed]

4. Steel, Z.; Chey, T.; Silove, D.; Marnane, C.; Bryant, R.A.; van Ommeren, M. Association of torture and other potentially traumatic events with mental health outcomes among populations exposed to mass conflict and displacement: A systematic review and meta-analysis. JAMA 2009, 302, 537-549. [CrossRef]

5. Ferry, F.R.; Brady, S.E.; Bunting, B.P.; Murphy, S.D.; Bolton, D.; O’Neill, S.M. The Economic Burden of PTSD in Northern Ireland. J. Trauma. Stress 2015, 28, 191-197. [CrossRef] [PubMed]

6. Bisson, J.; Andrew, M. Psychological treatment of post-traumatic stress disorder (PTSD). Cochrane Database Syst. Rev. 2007, CD003388.

7. Hoskins, M.; Pearce, J.; Bethell, A.; Dankova, L.; Barbui, C.; Tol, W.A. Pharmacotherapy for post-traumatic stress disorder: Systematic review and meta-analysis. Br. J. Psychiatry 2015, 206, 93-100. [CrossRef]

8. Miller, D.D.; Caroff, S.N.; Davis, S.M.; Rosenheck, R.A.; McEvoy, J.P.; Saltz, B.L. Extrapyramidal side-effects of antipsychotics in a randomised trial. Br. J. Psychiatry 2008, 193, 279-288. [CrossRef]

9. Maneshi, M.; Vahdat, S.; Fahoum, F.; Grova, C.; Gotman, J. Specific resting-state brain networks in mesial temporal lobe epilepsy. Front. Neurol. 2014, 5, 127. [CrossRef] [PubMed]

10. Boccia, M.; D’Amico, S.; Bianchini, F.; Marano, A.; Giannini, A.M.; Piccardi, L. Different neural modifications underpin PTSD after different traumatic events: An fMRI meta-analytic study. Brain Imaging Behav. 2016, 10, 226-237. [CrossRef]

11. Cisler, J.M.; Steele, J.S.; Lenow, J.K.; Smitherman, S.; Everett, B.; Messias, E. Functional reorganization of neural networks during repeated exposure to the traumatic memory in posttraumatic stress disorder: An exploratory fMRI study. J. Psychiatr. Res. 2014, 48, 47-55. [CrossRef] 
12. Fahoum, F.; Lopes, R.; Pittau, F.; Dubeau, F.; Gotman, J. Widespread epileptic networks in focal epilepsies: EEG-fMRI study. Epilepsia 2012, 53, 1618-1627. [CrossRef] [PubMed]

13. Fiddick, L. There is more than the amygdala: Potential threat assessment in the cingulate cortex. Neurosci. Biobehav. Rev. 2011, 35, 1007-1018. [CrossRef] [PubMed]

14. Thijs, R.D.; Surges, R.; O’Brien, T.J.; Sander, J.W. Epilepsy in adults. Lancet 2019, 393, 689-701. [CrossRef]

15. Jafarian, M.; Modarres Mousavi, S.M.; Alipour, F.; Aligholi, H.; Noorbakhsh, F.; Ghadipasha, M. Cell injury and receptor expression in the epileptic human amygdala. Neurobiol. Dis. 2019, 124, 416-427. [CrossRef]

16. Ali, S.O.; Shahin, N.N.; Safar, M.M.; Rizk, S.M. Therapeutic potential of endothelial progenitor cells in a rat model of epilepsy: Role of autophagy. J. Adv. Res. 2019, 18, 101-112. [CrossRef] [PubMed]

17. Milczarek, O.; Jarocha, D.; Starowicz-Filip, A.; Kwiatkowski, S.; Badyra, B.; Majka, M. Multiple Autologous Bone Marrow-Derived CD271(+) Mesenchymal Stem Cell Transplantation Overcomes Drug-Resistant Epilepsy in Children. Stem Cells Transl. Med. 2018, 7, 20-33. [CrossRef] [PubMed]

18. Ruschenschmidt, C.; Koch, P.G.; Brustle, O.; Beck, H. Functional properties of ES cell-derived neurons engrafted into the hippocampus of adult normal and chronically epileptic rats. Epilepsia 2005, 46 (Suppl. 5), 174-183. [CrossRef]

19. Trounson, A.; McDonald, C. Stem Cell Therapies in Clinical Trials: Progress and Challenges. Cell Stem Cell 2015, 17, 11-22. [CrossRef]

20. Huang, H.; Young, W.; Chen, L.; Feng, S.; Zoubi, Z.M.A.; Sharma, H.S. Clinical Cell Therapy Guidelines for Neurorestoration (IANR/CANR 2017). Cell Transplant 2018, 27, 310-324. [CrossRef] [PubMed]

21. Daley, G.Q.; Hyun, I.; Apperley, J.F.; Barker, R.A.; Benvenisty, N.; Bredenoord, A.L. Setting Global Standards for Stem Cell Research and Clinical Translation: The 2016 ISSCR Guidelines. Stem Cell Rep. 2016, 6, 787-797. [CrossRef] [PubMed]

22. Salgado, A.J.; Sousa, J.C.; Costa, B.M.; Pires, A.O.; Mateus-Pinheiro, A.; Teixeira, F.G. Mesenchymal stem cells secretome as a modulator of the neurogenic niche: Basic insights and therapeutic opportunities. Front. Cell. Neurosci. 2015, 9, 249. [CrossRef] [PubMed]

23. Fox, I.J.; Daley, G.Q.; Goldman, S.A.; Huard, J.; Kamp, T.J.; Trucco, M. Stem cell therapy. Use of differentiated pluripotent stem cells as replacement therapy for treating disease. Science 2014, 345, 1247391. [CrossRef]

24. Huang, L.; Zhou, X.; Tang, S. Optimization of frequency-doubled Er-doped fiber laser for miniature multiphoton endoscopy. J. Biomed. Opt. 2018, 23, 126503. [CrossRef]

25. Thomson, J.A.; Itskovitz-Eldor, J.; Shapiro, S.S.; Waknitz, M.A.; Swiergiel, J.J.; Marshall, V.S. Embryonic stem cell lines derived from human blastocysts. Science 1998, 282, 1145-1147. [CrossRef] [PubMed]

26. Takahashi, K.; Tanabe, K.; Ohnuki, M.; Narita, M.; Ichisaka, T.; Tomoda, K. Induction of pluripotent stem cells from adult human fibroblasts by defined factors. Cell 2007, 131, 861-872. [CrossRef]

27. Simonson, O.E.; Domogatskaya, A.; Volchkov, P.; Rodin, S. The safety of human pluripotent stem cells in clinical treatment. Ann. Med. 2015, 47, 370-380. [CrossRef] [PubMed]

28. Grealish, S.; Diguet, E.; Kirkeby, A.; Mattsson, B.; Heuer, A.; Bramoulle, Y. Human ESC-derived dopamine neurons show similar preclinical efficacy and potency to fetal neurons when grafted in a rat model of Parkinson's disease. Cell Stem Cell 2014, 15, 653-665. [CrossRef]

29. Lukovic, D.; Valdes-Sanchez, L.; Sanchez-Vera, I.; Moreno-Manzano, V.; Stojkovic, M.; Bhattacharya, S.S. Brief report: Astrogliosis promotes functional recovery of completely transected spinal cord following transplantation of hESC-derived oligodendrocyte and motoneuron progenitors. Stem Cells 2014, 32, 594-599. [CrossRef]

30. Perrier, A.; Peschanski, M. How can human pluripotent stem cells help decipher and cure Huntington's disease? Cell Stem Cell 2012, 11, 153-161. [CrossRef] [PubMed]

31. Scheiner, Z.S.; Talib, S.; Feigal, E.G. The potential for immunogenicity of autologous induced pluripotent stem cell-derived therapies. J. Biol. Chem. 2014, 289, 4571-4577. [CrossRef] [PubMed]

32. Irion, S.; Zabierowski, S.E.; Tomishima, M.J. Bringing Neural Cell Therapies to the Clinic: Past and Future Strategies. Mol. Ther. Methods Clin. Dev. 2017, 4, 72-82. [CrossRef] [PubMed]

33. Merkle, F.T.; Maroof, A.; Wataya, T.; Sasai, Y.; Studer, L.; Eggan, K. Generation of neuropeptidergic hypothalamic neurons from human pluripotent stem cells. Development 2015, 142, 633-643. [CrossRef]

34. Shi, Y.; Kirwan, P.; Livesey, F.J. Directed differentiation of human pluripotent stem cells to cerebral cortex neurons and neural networks. Nat. Protoc. 2012, 7, 1836-1846. [CrossRef] [PubMed]

35. Amoroso, M.W.; Croft, G.F.; Williams, D.J.; O'Keeffe, S.; Carrasco, M.A.; Davis, A.R. Accelerated high-yield generation of limb-innervating motor neurons from human stem cells. J. Neurosci. 2013, 33, 574-586. [CrossRef]

36. Kefalopoulou, Z.; Politis, M.; Piccini, P.; Mencacci, N.; Bhatia, K.; Jahanshahi, M. Long-term clinical outcome of fetal cell transplantation for Parkinson disease: Two case reports. JAMA Neurol. 2014, 71, 83-87. [CrossRef]

37. Iwanami, A.; Kaneko, S.; Nakamura, M.; Kanemura, Y.; Mori, H.; Kobayashi, S. Transplantation of human neural stem cells for spinal cord injury in primates. J. Neurosci. Res. 2005, 80, 182-190. [CrossRef]

38. Deng, X.; Liang, Y.; Lu, H.; Yang, Z.; Liu, R.; Wang, J. Co-transplantation of GDNF-overexpressing neural stem cells and fetal dopaminergic neurons mitigates motor symptoms in a rat model of Parkinson's disease. PLoS ONE 2013, 8, e80880. [CrossRef] [PubMed] 
39. Bachoud-Levi, A.C.; Perrier, A.L. Regenerative medicine in Huntington's disease: Current status on fetal grafts and prospects for the use of pluripotent stem cell. Rev. Neurol. (Paris) 2014, 170, 749-762. [CrossRef]

40. Gao, J.; Prough, D.S.; McAdoo, D.J.; Grady, J.J.; Parsley, M.O.; Ma, L. Transplantation of primed human fetal neural stem cells improves cognitive function in rats after traumatic brain injury. Exp. Neurol. 2006, 201, 281-292. [CrossRef]

41. Sakata, H.; Niizuma, K.; Yoshioka, H.; Kim, G.S.; Jung, J.E.; Katsu, M. Minocycline-preconditioned neural stem cells enhance neuroprotection after ischemic stroke in rats. J. Neurosci. 2012, 32, 3462-3473. [CrossRef]

42. Glass, J.D.; Boulis, N.M.; Johe, K.; Rutkove, S.B.; Federici, T.; Polak, M. Lumbar intraspinal injection of neural stem cells in patients with amyotrophic lateral sclerosis: Results of a phase I trial in 12 patients. Stem Cells 2012, 30, 1144-1151. [CrossRef] [PubMed]

43. Shin, J.C.; Kim, K.N.; Yoo, J.; Kim, I.S.; Yun, S.; Lee, H. Clinical Trial of Human Fetal Brain-Derived Neural Stem/Progenitor Cell Transplantation in Patients with Traumatic Cervical Spinal Cord Injury. Neural Plast. 2015, 2015, 630932. [CrossRef] [PubMed]

44. Kalladka, D.; Sinden, J.; Pollock, K.; Haig, C.; McLean, J.; Smith, W. Human neural stem cells in patients with chronic ischaemic stroke (PISCES): A phase 1, first-in-man study. Lancet 2016, 388, 787-796. [CrossRef]

45. Neirinckx, V.; Coste, C.; Rogister, B.; Wislet-Gendebien, S. Concise review: Adult mesenchymal stem cells, adult neural crest stem cells, and therapy of neurological pathologies: A state of play. Stem Cells Transl. Med. 2013, 2, 284-296. [CrossRef] [PubMed]

46. Yang, Y.J.; Li, X.L.; Xue, Y.; Zhang, C.X.; Wang, Y.; Hu, X. Bone marrow cells differentiation into organ cells using stem cell therapy. Eur. Rev. Med. Pharmacol. Sci. 2016, 20, 2899-2907. [PubMed]

47. Petrou, P.; Gothelf, Y.; Argov, Z.; Gotkine, M.; Levy, Y.S.; Kassis, I. Safety and Clinical Effects of Mesenchymal Stem Cells Secreting Neurotrophic Factor Transplantation in Patients With Amyotrophic Lateral Sclerosis: Results of Phase 1/2 and 2a Clinical Trials. JAMA Neurol. 2016, 73, 337-344. [CrossRef]

48. Diez-Tejedor, E.; Gutierrez-Fernandez, M.; Martinez-Sanchez, P.; Rodriguez-Frutos, B.; Ruiz-Ares, G.; Lara, M.L. Reparative therapy for acute ischemic stroke with allogeneic mesenchymal stem cells from adipose tissue: A safety assessment: A phase II randomized, double-blind, placebo-controlled, single-center, pilot clinical trial. J. Stroke Cerebrovasc. Dis. 2014, 23, 2694-2700. [CrossRef] [PubMed]

49. Satti, H.S.; Waheed, A.; Ahmed, P.; Ahmed, K.; Akram, Z.; Aziz, T. Autologous mesenchymal stromal cell transplantation for spinal cord injury: A Phase I pilot study. Cytotherapy 2016, 18, 518-522. [CrossRef]

50. Dahbour, S.; Jamali, F.; Alhattab, D.; Al-Radaideh, A.; Ababneh, O.; Al-Ryalat, N. Mesenchymal stem cells and conditioned media in the treatment of multiple sclerosis patients: Clinical, ophthalmological and radiological assessments of safety and efficacy. CNS Neurosci. Ther. 2017, 23, 866-874. [CrossRef] [PubMed]

51. Wang, S.; Cheng, H.; Dai, G.; Wang, X.; Hua, R.; Liu, X. Umbilical cord mesenchymal stem cell transplantation significantly improves neurological function in patients with sequelae of traumatic brain injury. Brain Res. 2013, 1532, 76-84. [CrossRef] [PubMed]

52. Hlebokazov, F.; Dakukina, T.; Ihnatsenko, S.; Kosmacheva, S.; Potapnev, M.; Shakhbazau, A. Treatment of refractory epilepsy patients with autologous mesenchymal stem cells reduces seizure frequency: An open label study. Adv. Med. Sci. 2017, 62, 273-279. [CrossRef] [PubMed]

53. Lalu, M.M.; McIntyre, L.; Pugliese, C.; Fergusson, D.; Winston, B.W.; Marshall, J.C. Safety of cell therapy with mesenchymal stromal cells (SafeCell): A systematic review and meta-analysis of clinical trials. PLoS ONE 2012, 7, e47559. [CrossRef] [PubMed]

54. Thurman, D.J.; Begley, C.E.; Carpio, A.; Helmers, S.; Hesdorffer, D.C.; Mu, J. The primary prevention of epilepsy: A report of the Prevention Task Force of the International League Against Epilepsy. Epilepsia 2018, 59, 905-914. [CrossRef]

55. Sander, J.W.; Hart, Y.M.; Johnson, A.L.; Shorvon, S.D. National General Practice Study of Epilepsy: Newly diagnosed epileptic seizures in a general population. Lancet 1990, 336, 1267-1271. [CrossRef]

56. Sepkuty, J.P.; Cohen, A.S.; Eccles, C.; Rafiq, A.; Behar, K.; Ganel, R. A neuronal glutamate transporter contributes to neurotransmitter GABA synthesis and epilepsy. J. Neurosci. 2002, 22, 6372-6379. [CrossRef] [PubMed]

57. Gottschalk, W.; Pozzo-Miller, L.D.; Figurov, A.; Lu, B. Presynaptic modulation of synaptic transmission and plasticity by brain-derived neurotrophic factor in the developing hippocampus. J. Neurosci. 1998, 18, 6830-6839. [CrossRef] [PubMed]

58. Steffens, M.; Huppertz, H.J.; Zentner, J.; Chauzit, E.; Feuerstein, T.J. Unchanged glutamine synthetase activity and increased NMDA receptor density in epileptic human neocortex: Implications for the pathophysiology of epilepsy. Neurochem. Int. 2005, 47, 379-384. [CrossRef] [PubMed]

59. Norwood, B.A.; Bumanglag, A.V.; Osculati, F.; Sbarbati, A.; Marzola, P.; Nicolato, E. Classic hippocampal sclerosis and hippocampal-onset epilepsy produced by a single "cryptic" episode of focal hippocampal excitation in awake rats. J. Comp. Neurol. 2010, 518, 3381-3407. [CrossRef]

60. Mathern, G.W.; Babb, T.L.; Vickrey, B.G.; Melendez, M.; Pretorius, J.K. The clinical-pathogenic mechanisms of hippocampal neuron loss and surgical outcomes in temporal lobe epilepsy. Brain 1995, 118, 105-118. [CrossRef]

61. Cendes, F.; Leproux, F.; Melanson, D.; Ethier, R.; Evans, A.; Peters, T. MRI of amygdala and hippocampus in temporal lobe epilepsy. J. Comput. Assist. Tomogr. 1993, 17, 206-210. [CrossRef] [PubMed]

62. Kienzler, F.; Norwood, B.A.; Sloviter, R.S. Hippocampal injury, atrophy, synaptic reorganization, and epileptogenesis after perforant pathway stimulation-induced status epilepticus in the mouse. J. Comp. Neurol. 2009, 515, 181-196. [CrossRef] [PubMed]

63. Bertram, E.H. Temporal lobe epilepsy: Where do the seizures really begin? Epilepsy Behav. 2009, 14 (Suppl. 1), 32-37. [CrossRef] [PubMed] 
64. Parrent, A.G.; Blume, W.T. Stereotactic amygdalohippocampotomy for the treatment of medial temporal lobe epilepsy. Epilepsia 1999, 40, 1408-1416. [CrossRef]

65. Robbins, R.J.; Brines, M.L.; Kim, J.H.; Adrian, T.; de Lanerolle, N.; Welsh, S. A selective loss of somatostatin in the hippocampus of patients with temporal lobe epilepsy. Ann. Neurol. 1991, 29, 325-332. [CrossRef]

66. Levesque, M.; Avoli, M. The kainic acid model of temporal lobe epilepsy. Neurosci. Biobehav. Rev. 2013, 37, 2887-2899. [CrossRef]

67. Kucker, S.; Tollner, K.; Piechotta, M.; Gernert, M. Kindling as a model of temporal lobe epilepsy induces bilateral changes in spontaneous striatal activity. Neurobiol. Dis. 2010, 37, 661-672. [CrossRef] [PubMed]

68. Ryu, B.; Nagappan, S.; Santos-Valencia, F.; Lee, P.; Rodriguez, E.; Lackie, M. Chronic loss of inhibition in piriform cortex following brief, daily optogenetic stimulation. Cell Rep. 2021, 35, 109001. [CrossRef]

69. Van Dycke, A.; Raedt, R.; Verstraete, A.; Theofilas, P.; Wadman, W.; Vonck, K. Astrocytes derived from fetal neural progenitor cells as a novel source for therapeutic adenosine delivery. Seizure 2010, 19, 390-396. [CrossRef] [PubMed]

70. de Gois da Silva, M.L.; da Silva Oliveira, G.L.; de Oliveira Bezerra, D.; da Rocha Neto, H.J.; Feitosa, M.L.T.; Argolo Neto, N.M. Neurochemical properties of neurospheres infusion in experimental-induced seizures. Tissue Cell 2018, 54, 47-54. [CrossRef] [PubMed]

71. Papazian, I.; Kyrargyri, V.; Evangelidou, M.; Voulgari-Kokota, A.; Probert, L. Mesenchymal Stem Cell Protection of Neurons against Glutamate Excitotoxicity Involves Reduction of NMDA-Triggered Calcium Responses and Surface GluR1, and Is Partly Mediated by TNF. Int. J. Mol. Sci. 2018, 19, 651. [CrossRef]

72. Acharya, M.M.; Christie, L.A.; Lan, M.L.; Donovan, P.J.; Cotman, C.W.; Fike, J.R. Rescue of radiation-induced cognitive impairment through cranial transplantation of human embryonic stem cells. Proc. Natl. Acad. Sci. USA 2009, 106, 19150-19155. [CrossRef]

73. Xian, P.; Hei, Y.; Wang, R.; Wang, T.; Yang, J.; Li, J. Mesenchymal stem cell-derived exosomes as a nanotherapeutic agent for amelioration of inflammation-induced astrocyte alterations in mice. Theranostics 2019, 9, 5956-5975. [CrossRef] [PubMed]

74. Backofen-Wehrhahn, B.; Gey, L.; Broer, S.; Petersen, B.; Schiff, M.; Handreck, A. Anticonvulsant effects after grafting of rat, porcine, and human mesencephalic neural progenitor cells into the rat subthalamic nucleus. Exp. Neurol. 2018, 310, 70-83. [CrossRef]

75. Shetty, A.K.; Upadhya, D. GABA-ergic cell therapy for epilepsy: Advances, limitations and challenges. Neurosci. Biobehav. Rev. 2016, 62, 35-47. [CrossRef] [PubMed]

76. Karstoft, K.I.; Galatzer-Levy, I.R.; Statnikov, A.; Li, Z.; Shalev, A.Y.; members of Jerusalem Trauma Outreach. Bridging a translational gap: Using machine learning to improve the prediction of PTSD. BMC Psychiatry 2015, 15, 30. [CrossRef]

77. Knipscheer, J.; Sleijpen, M.; Frank, L.; de Graaf, R.; Kleber, R.; Ten Have, M. Prevalence of Potentially Traumatic Events, Other Life Events and Subsequent Reactions Indicative for Posttraumatic Stress Disorder in the Netherlands: A General Population Study Based on the Trauma Screening Questionnaire. Int. J. Environ. Res. Public Health 2020, 17, 1725. [CrossRef] [PubMed]

78. Calhoun, P.S.; Hertzberg, J.S.; Kirby, A.C.; Dennis, M.F.; Hair, L.P.; Dedert, E.A. The effect of draft DSM-V criteria on posttraumatic stress disorder prevalence. Depress. Anxiety 2012, 29, 1032-1042. [CrossRef]

79. Qassem, T.; Aly-ElGabry, D.; Alzarouni, A.; Abdel-Aziz, K.; Arnone, D. Psychiatric Co-Morbidities in Post-Traumatic Stress Disorder: Detailed Findings from the Adult Psychiatric Morbidity Survey in the English Population. Psychiatr. Q. 2021, 92, 321-330. [CrossRef]

80. Kessler, R.C.; Sonnega, A.; Bromet, E.; Hughes, M.; Nelson, C.B. Posttraumatic stress disorder in the National Comorbidity Survey. Arch. Gen. Psychiatry 1995, 52, 1048-1060. [CrossRef] [PubMed]

81. Kar, N. Cognitive behavioral therapy for the treatment of post-traumatic stress disorder: A review. Neuropsychiatr. Dis. Treat. 2011, 7, 167-181. [CrossRef] [PubMed]

82. Perez Benitez, C.I.; Zlotnick, C.; Stout, R.I.; Lou, F.; Dyck, I.; Weisberg, R. A 5-year longitudinal study of posttraumatic stress disorder in primary care patients. Psychopathology 2012, 45, 286-293. [CrossRef] [PubMed]

83. Shin, L.M.; Liberzon, I. The neurocircuitry of fear, stress, and anxiety disorders. Neuropsychopharmacology 2010, 35, 169-191. [CrossRef] [PubMed]

84. Rauch, S.L.; Shin, L.M.; Wright, C.I. Neuroimaging studies of amygdala function in anxiety disorders. Ann. N. Y. Acad. Sci. 2003, 985, 389-410. [CrossRef]

85. Lanius, R.A.; Williamson, P.C.; Boksman, K.; Densmore, M.; Gupta, M.; Neufeld, R.W. Brain activation during script-driven imagery induced dissociative responses in PTSD: A functional magnetic resonance imaging investigation. Biol. Psychiatry 2002, 52, 305-311. [CrossRef]

86. Milad, M.R.; Wright, C.I.; Orr, S.P.; Pitman, R.K.; Quirk, G.J.; Rauch, S.L. Recall of fear extinction in humans activates the ventromedial prefrontal cortex and hippocampus in concert. Biol. Psychiatry 2007, 62, 446-454. [CrossRef]

87. Alvarez, R.P.; Biggs, A.; Chen, G.; Pine, D.S.; Grillon, C. Contextual fear conditioning in humans: Cortical-hippocampal and amygdala contributions. J. Neurosci. 2008, 28, 6211-6219. [CrossRef] [PubMed]

88. Lang, S.; Kroll, A.; Lipinski, S.J.; Wessa, M.; Ridder, S.; Christmann, C. Context conditioning and extinction in humans: Differential contribution of the hippocampus, amygdala and prefrontal cortex. Eur. J. Neurosci. 2009, 29, 823-832. [CrossRef]

89. Lonsdorf, T.B.; Haaker, J.; Kalisch, R. Long-term expression of human contextual fear and extinction memories involves amygdala, hippocampus and ventromedial prefrontal cortex: A reinstatement study in two independent samples. Soc. Cogn. Affect. Neurosci. 2014, 9, 1973-1983. [CrossRef]

90. Rougemont-Bucking, A.; Linnman, C.; Zeffiro, T.A.; Zeidan, M.A.; Lebron-Milad, K.; Rodriguez-Romaguera, J. Altered processing of contextual information during fear extinction in PTSD: An fMRI study. CNS Neurosci. Ther. 2011, 17, 227-236. [CrossRef] 
91. Garfinkel, S.N.; Abelson, J.L.; King, A.P.; Sripada, R.K.; Wang, X.; Gaines, L.M. Impaired contextual modulation of memories in PTSD: An fMRI and psychophysiological study of extinction retention and fear renewal. J. Neurosci. 2014, 34, 13435-13443. [CrossRef]

92. Bouton, M.E. Context, ambiguity, and unlearning: Sources of relapse after behavioral extinction. Biol. Psychiatry 2002, 52, 976-986. [CrossRef]

93. Coventry, P.A.; Meader, N.; Melton, H.; Temple, M.; Dale, H.; Wright, K. Psychological and pharmacological interventions for posttraumatic stress disorder and comorbid mental health problems following complex traumatic events: Systematic review and component network meta-analysis. PLoS Med. 2020, 17, e1003262. [CrossRef] [PubMed]

94. Steinert, C.; Hofmann, M.; Leichsenring, F.; Kruse, J. The course of PTSD in naturalistic long-term studies: High variability of outcomes. A systematic review. Nord. J. Psychiatry 2015, 69, 483-496. [CrossRef]

95. Ursano, R.J.; Bell, C.; Eth, S.; Friedman, M.; Norwood, A.; Pfefferbaum, B. Practice guideline for the treatment of patients with acute stress disorder and posttraumatic stress disorder. Am. J. Psychiatry 2004, 161, 3-31. [PubMed]

96. Hu, X.H.; Bull, S.A.; Hunkeler, E.M.; Ming, E.; Lee, J.Y.; Fireman, B. Incidence and duration of side effects and those rated as bothersome with selective serotonin reuptake inhibitor treatment for depression: Patient report versus physician estimate. J. Clin. Psychiatry 2004, 65, 959-965. [CrossRef]

97. Hermes, E.; Sernyak, M.; Rosenheck, R. The use of second generation antipsychotics for post-traumatic stress disorder in a US Veterans Health Administration Medical Center. Epidemiol. Psychiatr. Sci. 2014, 23, 281-288. [CrossRef]

98. Jinno, S.; Klausberger, T.; Marton, L.F.; Dalezios, Y.; Roberts, J.D.; Fuentealba, P. Neuronal diversity in GABAergic long-range projections from the hippocampus. J. Neurosci. 2007, 27, 8790-8804. [CrossRef]

99. Zijlmans, M.; van Campen, J.S.; de Weerd, A. Post traumatic stress-sensitive epilepsy. Seizure 2017, 52, 20-21. [CrossRef]

100. Giotakos, O. Neurobiology of emotional trauma. Psychiatriki 2020, 31, 162-171. [CrossRef]

101. Liu, Q.; Zhang, L.; Zhang, J. Induced pluripotent stem cell-derived neural progenitor cell transplantation promotes regeneration and functional recovery after post-traumatic stress disorder in rats. Biomed. Pharmacother. 2021, 133, 110981. [CrossRef]

102. Saur, L.; Baptista, P.P.; Bagatini, P.B.; Neves, L.T.; de Oliveira, R.M.; Vaz, S.P. Experimental Post-traumatic Stress Disorder Decreases Astrocyte Density and Changes Astrocytic Polarity in the CA1 Hippocampus of Male Rats. Neurochem. Res. 2016, 41, 892-904. [CrossRef]

103. Andero, R.; Ressler, K.J. Fear extinction and BDNF: Translating animal models of PTSD to the clinic. Genes Brain Behav. 2012, 11, 503-512. [CrossRef] [PubMed]

104. Tynan, R.J.; Beynon, S.B.; Hinwood, M.; Johnson, S.J.; Nilsson, M.; Woods, J.J. Chronic stress-induced disruption of the astrocyte network is driven by structural atrophy and not loss of astrocytes. Acta Neuropathol. 2013, 126, 75-91. [CrossRef] [PubMed]

105. Thelin, E.P.; Hall, C.E.; Tyzack, G.E.; Frostell, A.; Giorgi-Coll, S.; Alam, A. Delineating Astrocytic Cytokine Responses in a Human Stem Cell Model of Neural Trauma. J. Neurotrauma 2020, 37, 93-105. [CrossRef] [PubMed]

106. Neigh, G.N.; Ali, F.F. Co-morbidity of PTSD and immune system dysfunction: Opportunities for treatment. Curr. Opin. Pharmacol. 2016, 29, 104-110. [CrossRef] [PubMed]

107. Lorente, I.L.; Xie, Y.; Mazzitelli, J.A.; Hatanaka, E.A.; Cinkornpumin, J.; Miller, D.R. Patient-derived glial enriched progenitors repair functional deficits due to white matter stroke and vascular dementia in rodents. Sci. Transl. Med. 2021, $13,102458$.

108. Lee, H.J.; Lim, I.J.; Park, S.W.; Kim, Y.B.; Ko, Y.; Kim, S.U. Human neural stem cells genetically modified to express human nerve growth factor (NGF) gene restore cognition in the mouse with ibotenic acid-induced cognitive dysfunction. Cell Transplant. 2012, 21, 2487-2496. [CrossRef]

109. Yang, H.; Xie, Z.; Wei, L.; Yang, H.; Yang, S.; Zhu, Z. Human umbilical cord mesenchymal stem cell-derived neuron-like cells rescue memory deficits and reduce amyloid-beta deposition in an AbetaPP/PS1 transgenic mouse model. Stem Cell Res. Ther. 2013, 4, 76. [CrossRef] [PubMed]

110. Xuan, A.G.; Long, D.H.; Gu, H.G.; Yang, D.D.; Hong, L.P.; Leng, S.L. BDNF improves the effects of neural stem cells on the rat model of Alzheimer's disease with unilateral lesion of fimbria-fornix. Neurosci. Lett. 2008, 440, 331-335. [CrossRef]

111. Koh, S.H.; Kim, K.S.; Choi, M.R.; Jung, K.H.; Park, K.S.; Chai, Y.G. Implantation of human umbilical cord-derived mesenchymal stem cells as a neuroprotective therapy for ischemic stroke in rats. Brain Res. 2008, 1229, 233-248. [CrossRef] [PubMed]

112. Ajami, B.; Bennett, J.L.; Krieger, C.; Tetzlaff, W.; Rossi, F.M. Local self-renewal can sustain CNS microglia maintenance and function throughout adult life. Nat. Neurosci. 2007, 10, 1538-1543. [CrossRef] [PubMed]

113. Riordan, N.H.; Hincapie, M.L.; Morales, I.; Fernandez, G.; Allen, N.; Leu, C. Allogeneic Human Umbilical Cord Mesenchymal Stem Cells for the Treatment of Autism Spectrum Disorder in Children: Safety Profile and Effect on Cytokine Levels. Stem Cells Transl. Med. 2019, 8, 1008-1016. [CrossRef]

114. Datta, D.; Subburaju, S.; Kaye, S.; Baruah, J.; Choi, Y.K.; Nian, Y. Human forebrain endothelial cell therapy for psychiatric disorders. Mol. Psychiatry 2020, PMCID:PMCPMC8162704. [CrossRef] [PubMed]

115. Kipper, F.C.; Angolano, C.; Vissapragada, R.; Contreras, M.A.; Moore, J.; Bhasin, M. Embryonic periventricular endothelial cells demonstrate a unique pro-neurodevelopment and anti-inflammatory gene signature. Sci. Rep. 2020, 10, 20393. [CrossRef] [PubMed]

116. Vasudevan, A.; Long, J.E.; Crandall, J.E.; Rubenstein, J.L.; Bhide, P.G. Compartment-specific transcription factors orchestrate angiogenesis gradients in the embryonic brain. Nat. Neurosci. 2008, 11, 429-439. [CrossRef]

117. Li, S.; Kumar, T.P.; Joshee, S.; Kirschstein, T.; Subburaju, S.; Khalili, J.S. Endothelial cell-derived GABA signaling modulates neuronal migration and postnatal behavior. Cell Res. 2018, 28, 221-248. [CrossRef] 